\title{
9. 鋼管分科会の経緯
}

\begin{tabular}{|c|c|c|c|c|}
\hline 回数 & & 開 催 日 & 所 & 題 \\
\hline 1 & $\mathrm{~S}$ & $30.6 / 10.11$ & $\begin{array}{l}\text { 日本パイプ(市川) } \\
\text { 日 本 鋼 管 (川崎) }\end{array}$ & $\begin{array}{l}\text { 1. 鋼管分科会発足に関する件 } \\
\text { 2. 帯鋼のスケール除去法について } \\
\text { 3. 冷間抽伸油の試験法 } \\
\text { 4. 文献紹介 } \\
\text { 5. 工場見学 } \\
\text { 6. 次回の打合わせ }\end{array}$ \\
\hline 2 & $\mathrm{~S}$ & $30.11 / 25.26$ & $\begin{array}{l}\text { 住 友金属 (鋼管) } \\
\text { 川 崎 製 鉄 (西宮) }\end{array}$ & $\begin{array}{l}\text { 1. 鋼管に発生する疵について } \\
\text { 2. 鋼管の錆止め塗装について } \\
\text { 3. 溶接鋼管製造における带鋼の第 } 2 \text { 処理工程について }\end{array}$ \\
\hline 3 & $\mathrm{~S}$ & $31.5 / 25.26$ & $\begin{array}{l}\text { 八幡 鋼 管(東京) } \\
\text { 東 芝 鋼 管 }\end{array}$ & $\begin{array}{l}\text { 1. 鋼管の内面筋について } \\
\text { 2. 電気抵抗溶接帯鋼の鋼種別（キルド鋼，中炭素鋼，合金鋼）の } \\
\text { 溶接性について } \\
\text { 3. Billet Conditioning について } \\
\text { 4. 溶接鋼管製造における第了処理工程について }\end{array}$ \\
\hline 4 & $s$ & $31.11 / 16.17$ & $\begin{array}{l}\text { 日本パイプ(尼崎) } \\
\text { 住友金属 (和歌山) }\end{array}$ & $\begin{array}{l}\text { 1. ピアサーについて } \\
\text { 2. 鋼管の内面疵について } \\
\text { 3. 溶接鋼管製造における帯鋼の第 } 4 \text { 処理工程 } \\
\text { 4. 溶接, 鍛接鋼管の検査方法および鋼種と溶接性との関係 }\end{array}$ \\
\hline 5 & $\mathrm{~S}$ & 32. $5 / 24.25$ & 日 本 鋼;,管(川崎) & $\begin{array}{l}\text { 1. ブラグミルおよびリーラーについて } \\
\text { 2. 鋼の曲りについて } \\
\text { 3. 杫目無と溶接鋼管共通とする } \\
\text { 4. 溶接鋼管製造における第 } 5 \text { 処理工程 }\end{array}$ \\
\hline 6 & $\mathrm{~s}$ & $32.11 / 15.16$ & $\begin{array}{l}\text { 川崎製 鉄 (西宮) } \\
\text { 住 友金属 (鋼管) }\end{array}$ & $\begin{array}{l}\text { 1. サイザーレデューサーについて } \\
\text { 2. 溶接鋼管製造法の特質 } \\
\text { 3. 仕上げ寸法と Dia. Reduction について } \\
\text { 4. サイザーレデューサーの各種圧延圧力およびその他について } \\
\text { 5. 第 } 1 \sim \text { 第 } 5 \text { 処理工程の比較検討 }\end{array}$ \\
\hline 7 & $\mathrm{~s}$ & 32. $5 / 23.24$ & 富 士 工 機 (中津) & $\begin{array}{l}\text { 1. 溶接管関係稼働状況について } \\
\text { 2. 溶接管関係設備保全について } \\
\text { 3. Plug mill 製管方式および全体配置について } \\
\text { 4. 全体の Rolling Schedule について } \\
\text { 5. Billet Conditioning について } \\
\text { 6. Piercer について } \\
\text { 7. Plug mill, Reeler について } \\
\text { 8. Sizer, Reducer について }\end{array}$ \\
\hline$: 8$ & $S$ & $33.12 / 9.10$ & $\begin{array}{l}\text { 日本パイプ(市川) } \\
\text { 日 本 特 殊 鋼 管 }\end{array}$ & $\begin{array}{l}\text { 1. 鋼管の (ガス管) 精整設備 } \\
\text { 2. 鋼管の矯正による管に対する影響について }\end{array}$ \\
\hline 9 & $\mathrm{~S}$ & 34. $5 / 22.23$ & $\begin{array}{l}\text { 川崎 製 鉄 (西宮) } \\
\text { 住友金属 (和歌山) }\end{array}$ & 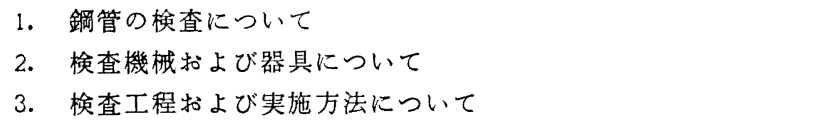 \\
\hline 10 & $\mathrm{~s}$ & $34.11 / 20.21$ & $\begin{array}{l}\text { 東芝 鋼 管(川崎) } \\
\text { 日 本 鋼 管(川崎) }\end{array}$ & $\begin{array}{l}\text { 1. 鋼管に発生する疵について } \\
\text { 2. 進行管理方式およびその実施について }\end{array}$ \\
\hline
\end{tabular}




\begin{tabular}{|c|c|c|c|c|}
\hline 回数 & 開 催 日 & 場 & 議 & 題 \\
\hline 11 & S $35.5 / 20.21$ & 鉄 & $\begin{array}{l}\text { 1. Operation に関する実状報告とその討議 } \\
\text { 2. 「疵の問題」に関する小委員の中間報告 }\end{array}$ & \\
\hline 12 & S $35.11 / 8.9$ & 日本特殊鋼管 (光) & $\begin{array}{l}\text { 1. Billet Conditioning について } \\
\text { 2. Hoop Conditioning について }\end{array}$ & \\
\hline 13 & S $36.6 / 9.10$ & $\begin{array}{l}\text { 富士三 機 }(川 \text { 崎 }) \\
\text { 八幡 鋼管 }(\text { 東京 })\end{array}$ & $\begin{array}{ll}\text { 1. Hoop の中間加工工程について } \\
\text { 2. 加熱炉执よびその操業について }\end{array}$ & \\
\hline 14 & S $36.11 / 10.11$ & $\begin{array}{l}\text { 住 友金属(尼崎) } \\
\text { 日本パイプ(尼崎) }\end{array}$ & $\begin{array}{l}\text { 1. 穿孔機構について } \\
\text { 2. Forming について }\end{array}$ & \\
\hline 15 & S 37. $5 / 23.24$ & $\begin{array}{l}\text { 日 本鉄 鋼連 盟 } \\
\text { 日本 鋼管 (川崎) }\end{array}$ & $\begin{array}{l}\text { 1. Welding Process について } \\
\text { 2. Forming Process について } \\
\text { 3. Seainless Pipe について }\end{array}$ & \\
\hline 16 & S $37.11 / 9.16$ & $\begin{array}{l}\text { 川崎 製 鉄 (西宮) } \\
\text { 住友金属 (和歌山) }\end{array}$ & & \\
\hline
\end{tabular}

\section{後 記}

本報告の提出のありました昭和38年 4 月以後におきまして，共同研究会鋼材部会は組織 の再編成を行ない, 昭和38年 8 月より鋼材部会は解散, 新らたに下記のごとく鋼板部会, 条鋼部会，鋼管部会に分れ研究活動を行なうこととなりました.

したがいまして本報告書を提出いたしました鋼管分科会は鋼管部会となりました。

(日本跌鋼協会事務局)

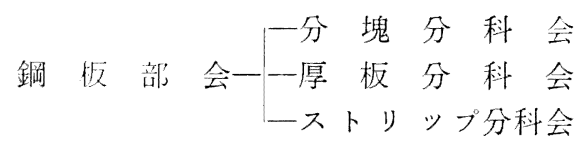

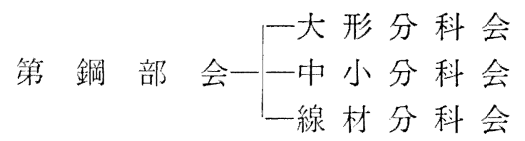

鋼 管 部 会一 